\title{
Intracellular survival and saprophytic growth of isolates from the Burkholderia cepacia complex in free-living amoebae
}

\author{
Cristina L. Marolda,' Bărbel Hauröder, ${ }^{2}$ Michael A. John, ${ }^{1,3}$ Rolf Michel $^{2}$ \\ and Miguel A. Valvano ${ }^{1}$
} Author for correspondence: Miguel A. Valvano. Tel: +1 5196613996. Fax: +1 5196613499.
e-mail: mvalvano@julian.uwo.ca

\author{
1 Department of \\ Microbiology and \\ Immunology and Division \\ of Clinical Microbiology, \\ University of Western \\ Ontario, London, Ontario, \\ Canada, N6A 5C1 \\ 2 Ernst-Rodenwaldt-Institut, \\ Koblenz D-56065, \\ Germany \\ 3 Department of \\ Microbiology and Infection \\ Control, London Health \\ Sciences Centre, London, \\ Ontario, Canada, N6A 4G5
}

\begin{abstract}
Members of the taxonomically diverse Burkholderia cepacia complex have become a major health risk for patients with cystic fibrosis (CF). Although patient-to-patient transmission of $B$. cepacia strains has been welldocumented, very little is known about possible vehicles of transmission and reservoirs for these micro-organisms. In this work, it is shown that strains of the $B$. cepacia complex can survive within different isolates of the genus Acanthamoeba. Trophozoites containing bacteria developed profuse cytoplasmic vacuolization. Vacuolization was not detected in trophozoites infected with live Escherichia coli or heat-killed B. cepacia, or by incubation of trophozoites with filter-sterilized culture supernatants, indicating that metabolically active intracellular bacteria are required for the formation of vacuoles. Experiments with two different $B$. cepacia strains and two different Acanthamoeba isolates revealed that bacteria display a low level of intracellular replication approximately $72-96 \mathrm{~h}$ following infection. In contrast, extracellular bacteria multiplied efficiently on by-products released by amoebae. The findings suggest that amoebae may be a reservoir for $B$. cepacia and possibly a vehicle for transmission of this opportunistic pathogen among CF patients.
\end{abstract}

Keywords: Burkholderia cepacia, Acanthamoeba, cystic fibrosis, intracellular survival

\section{INTRODUCTION}

Burkbolderia cepacia is a soil micro-organism first described by Burkholder (1950) as the agent causing bacterial soft rot in onions. B. cepacia strains display an extraordinary metabolic versatility, being capable of degrading a wide variety of organic compounds, as well as surviving in nutritionally limited environments (Beckman \& Lessie, 1979). Such properties have attracted considerable interest from agricultural researchers attempting development of $B$. cepacia strains for use as biological control agents to combat soilborne plant pathogens, and to decontaminate soils containing toxic pesticides and herbicides (Govan \& Vandamme, 1998). However, in recent years B. cepacia has increasingly been found associated with life-threatening lung infections in humans, which may occur in patients requiring mechanical ventilation, as well as those with cystic fibrosis $(\mathrm{CF})$ and chronic granulomatous disease
(Govan et al., 1996; Govan \& Deretic, 1996; Isles et al., 1984; Tablan et al., 1985). Therapy of B. cepacia infections is problematic since these micro-organisms are intrinsically resistant to a wide range of antimicrobial agents (Prince, 1986). Recent taxonomic studies have shown that B. cepacia isolates, cultured from clinical or environmental sites, belong to at least five different genomovars, collectively referred to as the $B$. cepacia complex (Vandamme et al., 1997). The available taxonomic evidence indicates that there is no clear distinction between environmental and clinical species within the complex.

A major concern with B. cepacia in CF is that some strains can spread from patient-to-patient, both within and outside the hospital. Molecular typing of isolates from patients and contacts demonstrated that transmission is strain-specific (LiPuma et al., 1990). Clinical isolates can survive for long periods in respiratory droplets on environmental surfaces typically found in CF clinics (Drabick et al., 1996). Very little is known about vehicles for transmission of B. cepacia. Recently, 
Michel \& Hauröder (1997) reported the presence of intracellular Ralstonia (Burkholderia) pickettii in a strain of Acanthamoeba isolated from the tiles of a physiotherapy room. Free-living amoebae are widely distributed in the environment, and humans may frequently come into contact with these organisms, particularly with their resistant cysts (Mergeryan, 1991). Acanthamoeba and other types of amoebae can colonize humans and may be isolated from respiratory sources (De Jonckheere, 1991; Kilvington \& White, 1994; Michel \& Hauröder-Philippczyk, 1994). Intracellular survival of bacteria in amoebae offers additional protection against disinfectants (Kilvington \& Price, 1990) and may contribute to their enhanced environmental survival (Boulanger \& Edelstein, 1995). Microbial pathogens with well-established intracellular survival strategies in mammalian cells such as Legionella pneumophila, Mycobacterium avium, Chlamydia pneumoniae and Listeria monocytogenes have been shown to survive within amoebae (Birtles et al., 1997; Cirillo et al., 1997; Essig et al., 1997; Ly \& Muller, 1990; Rowbotham, 1980).

Since the genera Ralstonia and Burkholderia are taxonomically related, we hypothesized that $B$. cepacia would also be capable of intracellular survival in free-living amoebae. In the current study, we present evidence that clinical and environmental isolates belonging to different genomovars of the $B$. cepacia complex can survive within several different strains of the genus Acanthamoeba, and can also grow saprophytically on byproducts released by the amoebae. We propose that freeliving amoebae may be a reservoir for the acquisition, and perhaps transmission, of B. cepacia.

\section{METHODS}

Bacterial strains. Clinical isolates of B. cepacia were obtained from the Vancouver collection, the London Health Sciences Centre, and from an outbreak at the Nephrology Unit, CEMIC, Buenos Aires, Argentina. Many of these isolates were genetically differentiated into the various genomovars by $\mathrm{P}$. Vandamme, Laboratory of Microbiology, University of Gent, Belgium, and others by E. Mahenthiralingam, Department of Pediatrics, University of British Columbia, Vancouver, British Columbia, Canada. Environmental strains were obtained from the American Type Culture Collection. Escherichia coli DH5a, Enterobacter cloacae and Pseudomonas aeruginosa PAO1 were from our laboratory stocks. All strains were grown on Luria agar plates. For some experiments bacteria were grown in amoeba-conditioned medium. This medium was prepared by growing amoebae for $4 \mathrm{~d}$ at $25^{\circ} \mathrm{C}$ in Acanthamoeba buffer (see below). Amoebae were removed by centrifugation and the medium was filter-sterilized using a $0.22 \mu \mathrm{m}$ filter membrane (Millipore).

Amoebae. Acanthamoeba castellanii ATCC 30234 and Acanthamoeba polyphaga strain JAC/S2 (ATCC 50372) were obtained from the American Type Culture Collection, Manassas, VA, USA. Acanthamoeba spp. Vic-1 and HLA were clinical isolates from cases of human keratitis. Acanthamoeba sp. Wi III $8 / 2$ was isolated from the wet area of a hospital physiotherapy unit while A. castellanii strain $\mathrm{C} 3$ came from a water reservoir used for drinking water (Michel \& Hauröder, 1997). Amoebae were maintained axenically in peptone/yeast extract/glucose (PYG) medium (Page, 1976) at $25^{\circ} \mathrm{C}$ as monolayers in $25 \mathrm{~cm}^{2}$ flasks (Falcon 3018; Becton Dickinson). Cells were resuspended by tapping the flask, and cell counts were determined with a haemocytometer.

Infection of amoebae with bacteria. Amoebae and bacteria were cocultivated on non-nutrient agar (NNA) plates (Page, 1976). Axenically grown amoebae were washed with Acanthamoeba buffer (Page, 1976) and 200-300 cells were spotted in the centre of an NNA plate that had been seeded with $5 \times 10^{4}$ bacteria previously grown in Luria broth (LB) and washed twice with Acanthamoeba buffer. Plates were incubated at $25^{\circ} \mathrm{C}$ and observed daily by phase-contrast microscopy and differential interference microscopy for up to $15 \mathrm{~d}$.

Determination of intracellular multiplication of bacteria. Amoebae were grown to confluence in a $25 \mathrm{~cm}^{2}$ dish (Falcon 3018), washed three times with Acanthamoeba buffer, and counted with a haemocytometer. Aliquots $(1 \mathrm{ml})$ containing approximately $6 \times 10^{4}$ amoebae were placed in each well of a 24-well tissue culture dish (Falcon 3047) and allowed to settle for $2 \mathrm{~h}$. Bacteria from an overnight culture in Luria broth were washed and resuspended in Acanthamoeba buffer to an approximate density of $1.2 \times 10^{8}$ c.f.u. $\mathrm{ml}^{-1}$ and $100 \mu \mathrm{l}$ of this suspension was added to each well containing amoebae to give an approximate m.o.i. of 200. Dishes were centrifuged for $3 \mathrm{~min}$ at 1000 r.p.m. and incubated at $25^{\circ} \mathrm{C}$. Bacterial invasion was permitted to continue for $4 \mathrm{~h}$, after which time the wells were washed three times with Acanthamoeba buffer and $500 \mu \mathrm{g}$ ceftazidime $\mathrm{ml}^{-1}$ (Tazidime; Eli Lilly) to kill residual extracellular bacteria. One hundred microlitres of $10^{7}$ heatkilled E. coli was added to each well as a food source to avoid stress by starvation of amoebae. Wells were processed at 24 , $48,72,96,120$ and $144 \mathrm{~h}$. Processing at each time point was as follows. Buffer was carefully aspirated and the number of amoebae was counted using an inverted microscope. One millilitre of fresh Acanthamoeba buffer was added and a $100 \mu \mathrm{l}$ aliquot was sampled to determine the number of extracellular bacteria. One hundred microlitres of $20 \%$ Triton $\mathrm{X}-100$ (final concentration $0.4 \%$ ) was added to lyse the amoebae. The extent of lysis was monitored for $10-15 \mathrm{~min}$ under the inverted microscope until approximately $90 \%$ of the trophozoites were lysed. A $100 \mu \mathrm{l}$ aliquot of the lysate was taken for bacterial counts to determine the number of total bacteria (intracellular + extracellular bacteria). Wells to be processed at a later time were washed with Acanthamoeba buffer and ceftazidime, and heat-killed E. coli was added as indicated above. Bacterial counts were carried out as described by Jett et al. (1997). The number of intracellular bacteria was calculated by subtracting the number of extracellular bacteria from the number of total bacteria. All experiments were carried out in duplicate.

Electron microscopy. Co-cultures with amoebae and bacteria at different times were washed from agar plates and fixed in $2.5 \%$ glutaraldehyde $/ 4 \%$ paraformaldehyde buffered in cacodylate. Fixed samples were processed as previously described (Michel \& Hauröder, 1997) and examined in a Zeiss EM910 electron microscope.

\section{RESULTS}

\section{B. cepacia CEP021 survives within cytoplasmic vacuoles in Acanthamoeba spp. Vic-1 and HLA}

Initial cocultivation experiments were conducted with Acanthamoeba spp. Vic-1 and HLA and the B. cepacia complex genomovar VI strain CEP021. Cocultivations 

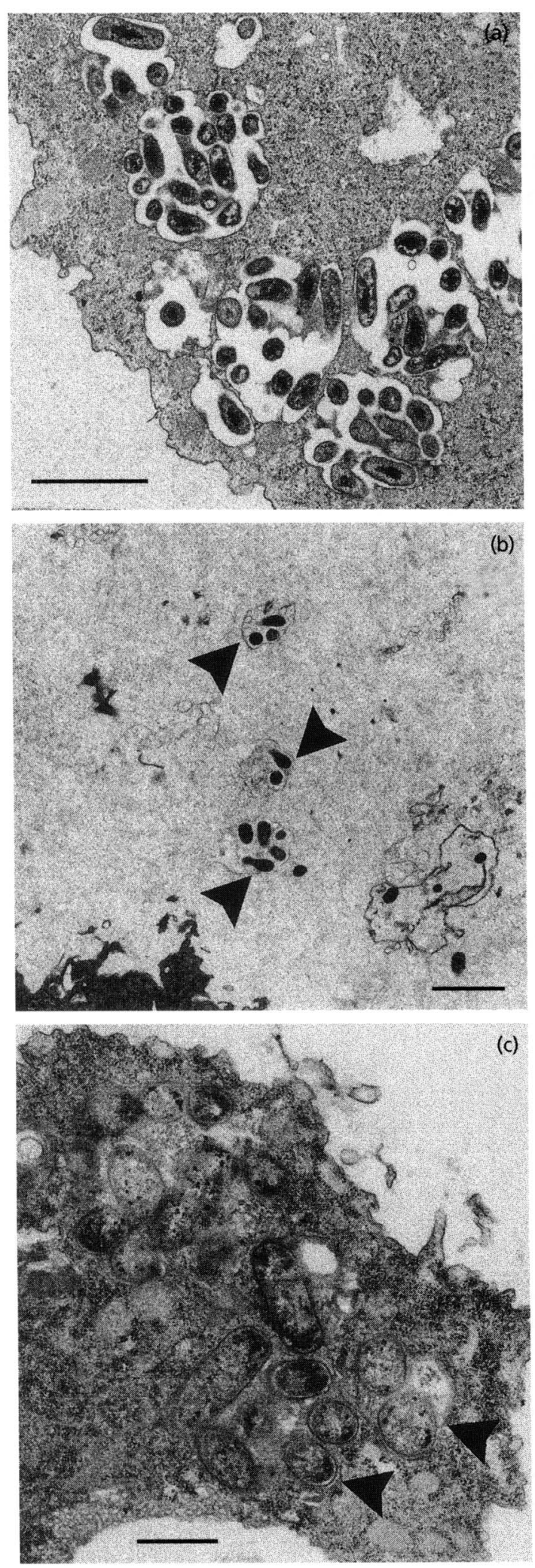

Fig. 1. Transmission electron microscopy of Acanthamoeba sp. HLA cells cocultivated with $B$. cepacia CEP021 and Ent. cloacae. (a) Trophozoites infected with $B$. cepacia after $5 d$ incubation showing spacious vacuoles with intact bacteria (bar, $2 \mu \mathrm{m}$ ). (b) Arrowheads indicate small membrane-bound vesicles containing bacteria drifting off a disintegrating amoeba (bar, were carried out by seeding NNA plates containing axenically grown trophozoites with $5 \times 10^{4}$ bacteria per plate and changes in the morphology of trophozoites were followed by phase-contrast and differential interference contrast microscopy. At approximately $48 \mathrm{~h}$ after infection, trophozoites on the agar surface began to show several vacuoles, which increased in size and number over $5 \mathrm{~d}$. Some trophozoites were completely filled with vacuoles. Motile bacteria were seen within giant vacuoles even after $15 \mathrm{~d}$ (data not shown). The trophozoites appeared to be viable since they were able to move on the agar plate, albeit with reduced motility, as the trophozoites became heavily vacuolated and round. In addition, the contractile vacuole remained free of bacteria, and was opening and closing normally, indicating that its function was preserved. In control experiments using live $E$. coli $\mathrm{DH} 5 \alpha$ or heat-killed $B$. cepacia CEP021, trophozoites did not show any abnormal vacuolization. A large number of cysts appeared on plates cocultivated with $E$. coli $\mathrm{DH} 5 \alpha$ after $3-4 \mathrm{~d}$ incubation. Combined data of four independent experiments revealed that after $4 \mathrm{~d}, 92 \pm 3 \%$ of the amoeba cells cocultivated with live E. coli $\mathrm{DH} 5 \alpha$ had formed cysts, while only $7 \pm 4 \%$ of cysts were found at a similar time point when trophozoites were infected with live CEP021 cells. Progressive encystation was found as a normal occurrence in amoebae fed with heat-killed $B$. cepacia, as well as with dead or live E. coli after several days of incubation. The absence of profuse encystation in plates infected with CEP021 suggested that B. cepacia infection interfered with the differentiation process from trophozoites into cysts. We also concluded from these experiments that extensive vacuolization was caused only by living bacteria. An experiment using filtersterilized bacterial culture supernatants from strain CEP021 did not show any apparent vacuolization of trophozoites, suggesting that the presence of microorganisms is required for vacuolization.

The localization of intracellular CEP021 organisms in vacuoles was confirmed by transmission electron microscopy. Fig. 1(a) shows intracellular bacteria in spacious vacuoles, surrounded by a membrane structure. Some of the bacteria showed indications of partial septa, suggesting intravacuolar replication. No bacteria were identified free in the cytoplasm, suggesting that they always remain within the phagocytic vacuole. No apparent changes in the fine structure of the mitochondria of the infected trophozoites were observed as has been documented in the case of amoebae infected by R. pickettii (Michel \& Hauröder, 1997). However, some amoeba cells appeared to be disintegrating, showing lamellated structures, some of which resemble myelinlike coils (data not shown). Intracellular bacteria in these cells remained intact within vacuoles or were observed drifting off disintegrating amoebae in small

$2 \mu \mathrm{m})$. (c) Amoeba cells cocultivated with Ent. cloacae showing tight-fitting vacuoles with bacteria (solid arrowheads) (bar, $1 \mu \mathrm{m})$. 
Table 1. Properties of strains of the $B$. cepacia complex examined in this study

\begin{tabular}{|c|c|c|c|c|c|}
\hline \multirow[t]{2}{*}{ Strain } & \multirow[t]{2}{*}{ Genomovar ${ }^{*}$} & \multirow[t]{2}{*}{ Source } & \multicolumn{3}{|c|}{ Infection in Acanthamoeba } \\
\hline & & & Vic-1 & $\begin{array}{l}\text { A. castellanii } \\
\mathbf{3 0 2 3 4}\end{array}$ & $\begin{array}{l}\text { A. polyphaga } \\
\text { JAC/S2 }\end{array}$ \\
\hline \multicolumn{6}{|l|}{ B. cepacia } \\
\hline ATCC 25416 & I & Onion & + & $(+)$ & + \\
\hline CEP163 & I & Soil & - & ND & + \\
\hline CEP509\$ & I & $\mathrm{CF}$ & ++ & + & + \\
\hline FC124\ & I & CGD & - & $(+)$ & - \\
\hline MC76 & I & Onion & ++ & + & + \\
\hline MC81 & I & Onion & + & ND & + \\
\hline MC135 & I & Soil & - & + & + \\
\hline MC353 & I & Onion & ++ & ND & $\mathrm{ND}$ \\
\hline C1484 & III & $\mathrm{CF}$ & + & $(+)$ & - \\
\hline C3865 & III & $\mathrm{CF}$ & + & ++ & + \\
\hline C4455 & III & $\mathrm{CF}$ & - & ND & - \\
\hline C5424\$ & III & $\mathrm{CF}$ & - & + & - \\
\hline C6061 & III & $\mathrm{CF}$ & - & $\mathrm{ND}$ & + \\
\hline СЕР024 & III & $\mathrm{CF}$ & - & $\mathrm{ND}$ & - \\
\hline CEP54 & III & $\mathrm{CF}$ & - & $\mathrm{ND}$ & - \\
\hline CEP511\$ & III & $\mathrm{CF}$ & - & $\mathrm{ND}$ & ND \\
\hline CP 706-J & III & $\mathrm{CF}$ & - & $\mathrm{ND}$ & ND \\
\hline F28369-82 & III & $\mathrm{CF}$ & + & $\mathrm{ND}$ & - \\
\hline F38192.89 & III & $\mathrm{CF}$ & $(+)$ & $\mathrm{ND}$ & ND \\
\hline L10 & III & $\mathrm{CF}$ & - & ND & + \\
\hline PC 527-I & III & $\mathrm{CF}$ & - & ND & ND \\
\hline PC 701-J & III & $\mathrm{CF}$ & - & ND & ND \\
\hline CEP559 & IV & $\mathrm{CF}$ & - & ND & - \\
\hline FC362 & IV & Soil & ND & ND & - \\
\hline FC473 & IV & $\mathrm{CF}$ & ND & $\mathrm{ND}$ & + \\
\hline CEP021\$ & VI & $\mathrm{CF}$ & ++ & - & + \\
\hline Ce1258 & Unknown & Blood & + & ND & + \\
\hline CEP455 & Unknown & CF & - & ND & - \\
\hline CEP493 & Unknown & $\mathrm{CF}$ & - & ND & $\mathrm{ND}$ \\
\hline CFLG & Unknown & $\mathrm{CF}$ & + & ND & + \\
\hline L6 & Unknown & $\mathrm{CF}$ & ++ & ++ & ++ \\
\hline MC366 & Unknown & Soil & + & ND & $\mathrm{ND}$ \\
\hline \multicolumn{6}{|c|}{ B. multivorans } \\
\hline C0514\$ & II & $\mathrm{CF}$ & - & ND & $(+)$ \\
\hline C3430\$ & II & $\mathrm{CF}$ & - & + & - \\
\hline C4297\$ & II & $\mathrm{CF}$ & - & ND & - \\
\hline C5274 & II & $\mathrm{CF}$ & $(+)$ & ND & - \\
\hline C5393 & II & CF & - & ND & - \\
\hline C5568 & II & $\mathrm{CF}$ & - & - & - \\
\hline C7072 & II & $\mathrm{CF}$ & - & + & + \\
\hline CEP484 & II & $\mathrm{CF}$ & - & ND & - \\
\hline \multicolumn{6}{|l|}{ B. gladioli } \\
\hline CEP89 & N/A & $\mathrm{CF}$ & ND & ND & + \\
\hline CEP22 & $\mathrm{N} / \mathrm{A}$ & $\mathrm{CF}$ & - & ND & + \\
\hline CEP30 & $\mathrm{N} / \mathrm{A}$ & CGD & - & + & + \\
\hline CEP32 & $\mathrm{N} / \mathrm{A}$ & Soil & ND & ND & - \\
\hline CEP654 & $\mathrm{N} / \mathrm{A}$ & $\mathrm{CF}$ & - & + & - \\
\hline
\end{tabular}


Table 1 (cont.)

\begin{tabular}{|c|c|c|c|c|c|}
\hline \multirow[t]{2}{*}{ Strain } & \multirow[t]{2}{*}{ Genomovar* } & \multirow[t]{2}{*}{ Source } & \multicolumn{3}{|c|}{ Infection in Acanthamoeba $\ddagger$} \\
\hline & & & Vic-1 & $\begin{array}{c}\text { A. castellanii } \\
30234\end{array}$ & $\begin{array}{c}\text { A. polyphaga } \\
\text { JAC/S2 }\end{array}$ \\
\hline \multicolumn{6}{|c|}{ B. vietnamiensis } \\
\hline $\mathrm{C} 2822$ & $\mathrm{~N} / \mathrm{A}$ & $\mathrm{CF}$ & + & ND & + \\
\hline CEP40 & $\mathrm{N} / \mathrm{A}$ & $\mathrm{CF}$ & ++ & + & +++ \\
\hline FC369 & $\mathrm{N} / \mathrm{A}$ & Soil & + & + & + \\
\hline FC441 & $\mathrm{N} / \mathrm{A}$ & CGD & + & ND & + \\
\hline FC466 & $\mathrm{N} / \mathrm{A}$ & $\mathrm{CF}$ & ND & ND & + \\
\hline \multicolumn{6}{|c|}{ P. aeruginosa } \\
\hline PAO1 & $\mathrm{N} / \mathrm{A}$ & Keratitis & +++ & ND & ND \\
\hline
\end{tabular}

* Genomovars I, II, III and IV were determined by P. Vandamme as previously described (Vandamme et al., 1997). Genomovar VI is a newly determined genomovar of the B. cepacia complex (P. Vandamme, personal communication). Unknown, genomovar assignment not done; N/A, not applicable.

†CF, cystic fibrosis; CGD, chronic granulomatous disease.

$\ddagger$ Infection was determined by the appearance of vacuoles containing bacteria in cocultivation assays performed on NNA plates incubated at $25^{\circ} \mathrm{C} .(+)$, Small vacuoles that disappeared after $72 \mathrm{~h}$ (abortive infection?); + , two or three vacuoles with motile bacteria appearing after $72 \mathrm{~h}$; ++ , five or more vacuoles with motile bacteria appearing after $72 \mathrm{~h} ;+++$, five or more vacuoles with motile bacteria appearing after $24 \mathrm{~h}$. ND, Not done.

$\$$ Same results as with Acanthamoeba sp. Vic-1 were obtained using Acanthamoeba sp. HLA.

vacuoles of approximately $5-6 \mu \mathrm{m}$ in size harbouring two to five intact bacteria (Fig. 1b). In contrast, examination of strain HLA trophozoites that had been fixed and embedded $72 \mathrm{~h}$ after addition of Ent. cloacae as a food source revealed that the ingested bacteria were enclosed by tightly fitting membranes of food vacuoles (Fig. 1c). Some of these bacterial cells appeared to be in a state of degradation, probably caused by lysosomal enzymes.

\section{Infection of amoebae is host-dependent and varies with the temperature of incubation}

To determine whether B. cepacia CEP021 could infect other amoeba isolates we conducted infections with $A$. castellanii 30234, A. castellanii C3, Acanthamoeba sp. Wi III $8 / 2$ and A. polyphaga JAC/S2. Vacuolization of trophozoites was observed in the case of $A$. polyphaga JAC/S2 (Table 1 and data not shown). However, neither A. castellanii 30234 nor Acanthamoeba sp. Wi III 8/2 and A. castellanii $\mathrm{C} 3$, which could be infected with $R$. pickettii (Michel \& Hauröder, 1997), were infected by $B$. cepacia CEP021. These results suggest that not all amoeba strains can support intracellular survival of $B$. cepacia.

Since temperature may affect the outcome of infection of amoebae in cocultivation assays we also examined the relationship between infection and growth temperature. Cocultivations were carried out at room temperature (approx. $20^{\circ} \mathrm{C}$ ), $25^{\circ} \mathrm{C}, 30^{\circ} \mathrm{C}$ and $37^{\circ} \mathrm{C}$. Uninfected trophozoites rapidly developed into cysts within $24-48 \mathrm{~h}$ upon incubation at $37^{\circ} \mathrm{C}$. The number of trophozoites infected with CEP021 rapidly declined and a substantial amount of debris was observed on the plates, suggesting that under these conditions infection with $B$. cepacia results in the rapid lysis of the amoebae. At 20,25 and $30{ }^{\circ} \mathrm{C}$ infections proceeded normally and uninfected amoebae in control plates looked healthy.

\section{B. cepacia complex strains can grow saprophytically in the presence of amoebae}

We carried out quantitative studies to determine whether isolates of $B$. cepacia can replicate intracellularly. For these experiments we utilized two strains of Acanthamoeba (A. polyphaga and Acanthamoeba sp. Vic-1) and two isolates of the B. cepacia complex (the genomovar I strain CEP509 and B. cepacia strain CEP021). We utilized ceftazidime (Burns et al., 1996) to kill extracellular bacteria since these strains are highly resistant to gentamicin. The experiments with the ceftazidime killing assay showed comparable results (Fig. 2) revealing a 15-20-fold increase in the number of intracellular bacteria between 96 and $120 \mathrm{~h}$ over the values at earlier time points. The number of extracellular bacteria remained low at all times. We also determined the mean number of bacteria per trophozoite, which demonstrated similar kinetics, ranging from 10 to 35 bacteria per trophozoite at $120 \mathrm{~h}$ in contrast to one to five bacteria per trophozoite at earlier time points (data not shown). Parallel control experiments using live $E$. 


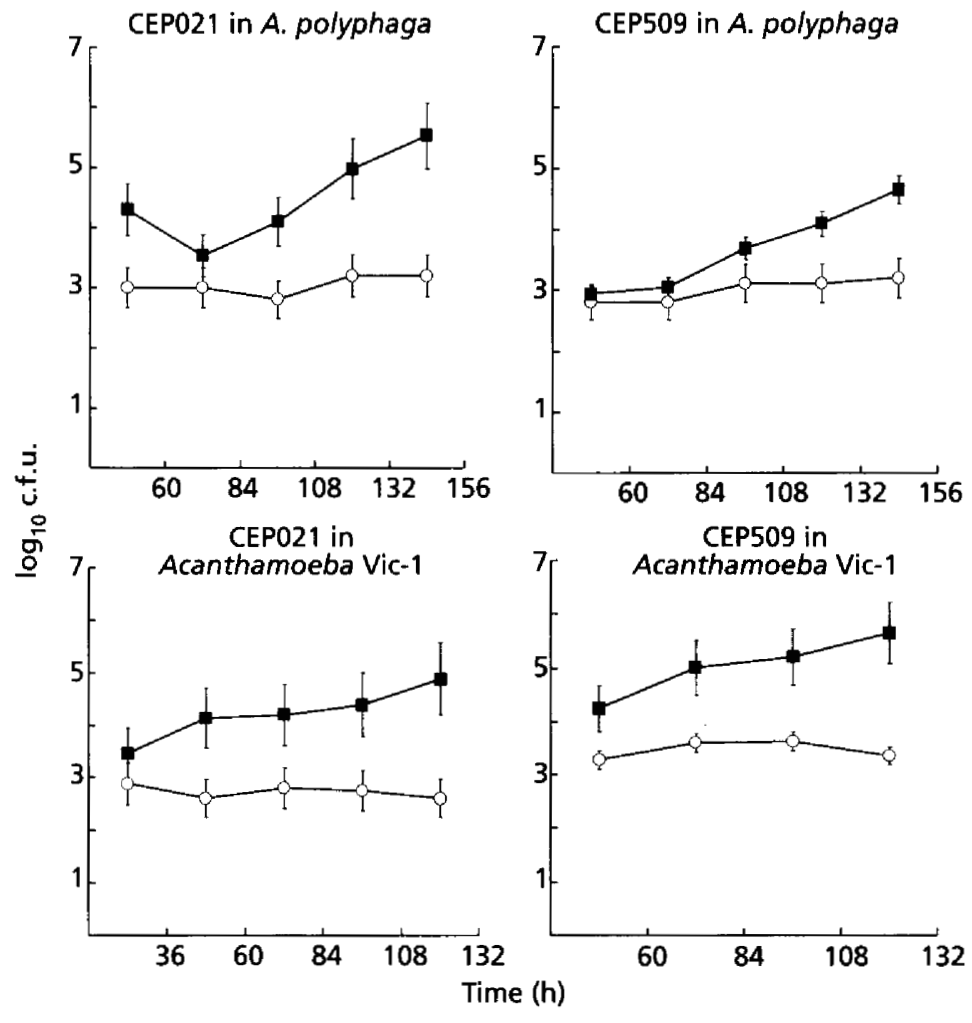

Fig. 2. Kinetics of intracellular growth of $B$. cepacia CEP021 (genomovar VI) and $B$. cepacia CEP509 (genomovar I) in $A$. polyphaga and Acanthamoeba sp. Vic-1. The data points are the mean of two independent experiments. $\boldsymbol{u}$, Intracellular bacteria; 0 , extracellular bacteria. coli $\mathrm{DH} 5 \alpha$ and Ent. cloacae revealed a mean of about 100 intracellular bacteria at $24 \mathrm{~h}$, and failed to detect any viable intracellular bacteria at 48,72 and $96 \mathrm{~h}$. The data are consistent with the fact that these microorganisms serve as a food source for the amoebae.

In preliminary experiments, we determined that ceftazidime at $500 \mu \mathrm{g} \mathrm{ml}^{-1}$ killed $99.9 \%$ of micro-organisms in Acanthamoeba buffer with an initial bacterial inoculum between $10^{4}$ and $10^{5}$ c.f.u. $\mathrm{ml}^{-1}$. However, previous experience with invasion assays as used in this study has revealed that antibiotics often fail to kill all extracellular bacteria in the presence of the eukaryotic cells (Elsinghorst, 1994). Therefore, we also examined the efficacy of antibiotic killing of extracellular bacteria in the presence of amoebae. In these experiments, ceftazidime was added as before, but bacteria were cultivated from medium supernatant without any washes. The results (Fig. 3) show that ceftazidime efficiently killed at least $99 \cdot 8 \%$ of the bacterial inoculum. The number of recovered bacteria following antibiotic treatment was less than 100 c.f.u. $\mathrm{ml}^{-1}$ at $24,72,96$ and $120 \mathrm{~h}$. We therefore concluded that the antibiotic treatment was effective in killing extracellular bacteria. It is also possible that some extracellular bacteria remained attached to the amoeba cell surface and therefore escaped killing by ceftazidime. This could easily be excluded by microscopic observation since strain CEP021 forms filamentous cells in Acanthamoeba buffer that are about five times the cell length of normal rods. Although many filamentous bacteria attached to amoebae were visible during the first $24 \mathrm{~h}$ following infection, none were seen beyond such time after inspecting 10 fields with a magnification of $\times 400$ (data not shown). We conclude, therefore, that the possibility of extracellular bacteria escaping killing by attaching to the amoebae is unlikely.

Additional experiments were conducted to determine the growth rate of bacteria in fresh Acanthamoeba buffer and in amoebae-conditioned Acanthamoeba buffer (see Methods). Fig. 3 shows that bacteria do not grow well in regular Acanthamoeba buffer but were capable of rapid growth in amoebae-conditioned medium. This suggests that by-products released to the medium by amoebae may contribute to the saprophytic growth of the B. cepacia CEP021. A comparison between the saprophytic growth rate and intracellular growth clearly shows that the former is the main mechanism of growth (Fig. 3). Therefore, we conclude that although $B$. cepacia can survive and probably even replicate at low levels intracellularly, replication is primarily extracellular and aided by the presence of by-products produced by amoebae.

\section{Infection experiments using various amoebae and clinical and environmental isolates of $B$. cepacia}

We investigated whether other isolates of the B. cepacia complex can infect amoebae using $A$. polyphaga JAC/ S2, A. castellanii 30234 and Acanthamoeba sp. Vic-1 as hosts. We screened several taxonomically well-characterized isolates belonging to known genomovars, as well as other isolates identified in the laboratory as B. cepacia but not genetically characterized as yet. Isolates from soil and onions were also used in this screen. Data in 


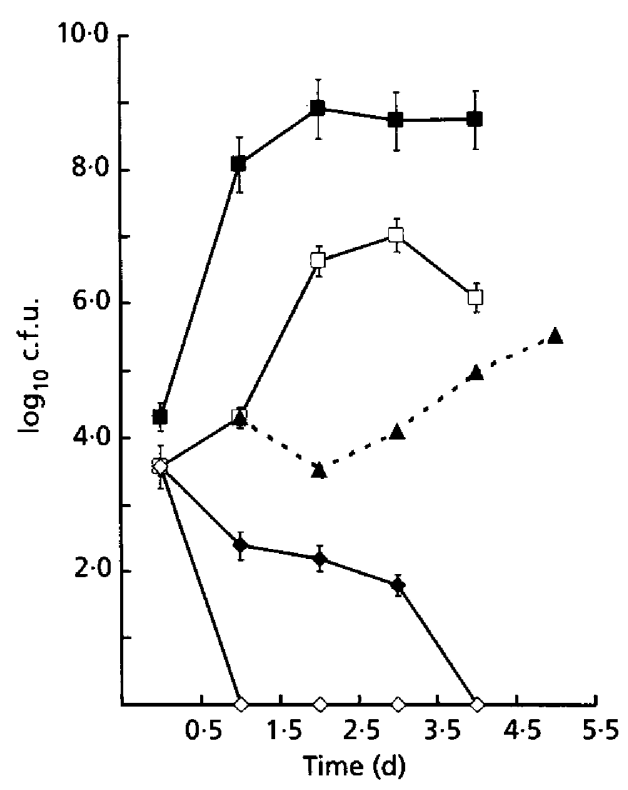

Fig. 3. Growth rate of B. cepacia CEP021 (genomovar VI) under different conditions. $\square$. Amoebae-conditioned medium, no amoebae, no antibiotic; $\square$. Acanthamoeba buffer with $A$. polyphaga, no antibiotic; $\bullet$. Acanthamoeba buffer, no amoebae, no antibiotic; $\diamond$. Acanthamoeba buffer with $A$. polyphaga $+500 \mu \mathrm{g}$ ceftazidime $\mathrm{ml}^{-1}$. For comparison, data from Fig. 2 corresponding to intracellular growth rate are also included $(\mathbf{A}-\ldots)$, except that error bars were omitted for clarity.

Table 1 show that strains causing vacuolization in amoebae were found in all genomovar groups of $B$. cepacia and also within Burkbolderia multivorans, Burkbolderia gladioli and Burkbolderia vietnamiensis. Most of the invasive bacteria caused extensive vacuolization of trophozoites $48-72 \mathrm{~h}$ following infection as previously observed with CEP021, and the vacuoles were also filled with motile bacteria. We also found some strains that took $72 \mathrm{~h}$ or more to induce the formation of visible vacuoles in the amoebae. In the case of strains ATCC 25416 in A. polyphaga and A. castellanii, B. multivorans $\mathrm{C} 5274$ and B. cepacia $\mathrm{F} 38192-$ 89 in Vic-1, and B. cepacia FC124 in A. castellanii, the cytoplasm of trophozoites was filled with small vacuoles during the first $3 \mathrm{~d}$ following infection. These vacuoles then disappeared, suggesting an abortive infection. Strain FC124 was unusual in that it appeared to be toxic for Acanthamoeba sp. Wi III 8/2, although it was unable to infect the other amoebae examined. $B$. multivorans C3430, B. gladioli CEP654 and B. cepacia C5424 were only moderately infective in $A$. castellanii 30234 . We also showed that intracellular survival was not restricted to $B$. cepacia, since $P$. aeruginosa strain PAO1 would cause vacuolization of Acanthamoeba sp. Vic-1 (Table 1 ), as has been shown previously with another strain of $P$. aeruginosa isolated from tap water (Michel \& Hauröder-Philippczyk, 1992). From all these results, we concluded that the property of intracellular survival within amoebae is not restricted to a single genomovar of the B. cepacia complex. Furthermore, our data suggest that it is useful to conduct vacuolization assays for $B$. cepacia isolates using a panel of various strains of amoebae to maximize the detection of isolates capable of intracellular survival.

\section{DISCUSSION}

We demonstrate in this study that many clinical and environmental isolates of $B$. cepacia belonging to all genomovars associated with $\mathrm{CF}$ are capable of intracellular survival in Acanthamoeba cells. Recently, Burns et al. (1996) reported that a clinical isolate of $B$. cepacia could invade and survive within a respiratory epithelial cell line. Also, B. cepacia-like micro-organisms are endosymbiotically associated with arbuscular mycorrhizal fungi, and reside within cytoplasmic vesicles (Perotto \& Bonfante, 1997). Our results add more support to the idea that isolates of the $B$. cepacia complex may be able to become intracellular at least at some stage during the infectious process. Preliminary data in our laboratory also show that B. cepacia CEP021 is capable of surviving within murine macrophages ( $\mathbf{L}$. Saini \& M. A. Valvano, unpublished). Intracellular survival in professional phagocytes may protect invading micro-organisms from antibiotics and host defences while promoting, at the same time, an enhanced inflammatory response that may ultimately cause lung tissue damage in CF patients.

We also propose that Acanthamoeba and perhaps other amoebae can serve as a reservoir for $B$. cepacia and may serve as vehicles for transmission of $B$. cepacia from patient to patient. The fact that infections of amoebae were more pronounced at $30^{\circ} \mathrm{C}$ is interesting, since in humans amoebae can be found colonizing the anterior nasal mucosa (De Jonckheere, 1991; Kilvington \& White, 1994) where the temperature is typically $30-$ $32^{\circ} \mathrm{C}$ (Willatt, 1993). Recently, it has been demonstrated that Acanthamoeba strains release membrane-bound vesicles with bacterial content (Berk et al., 1998). These vacuoles are $2-5 \mu \mathrm{m}$ in diameter on average, which means that they can be transported directly to the lower respiratory tract by the airflow. Bacteria in these vacuoles are presumably also protected from environmental conditions in the airways. Similar small vacuoles containing B. cepacia CEP021 were noticed in our study, suggesting that infected amoebae colonizing the upper respiratory tract could potentially disintegrate and release intracellular bacteria within vacuoles, facilitating the colonization and establishment of B. cepacia in the patients' airways. Respirable vesicles containing bacteria may also be breathed out, allowing person-toperson transmission and colonization of the environment. To test these ideas we are currently undertaking a clinical study to determine colonization by amoebae in patients with CF, as well as experiments with an animal model. It is possible that amoebae may also be a reservoir for strains of $P$. aeruginosa. In a previous work, the isolation of amoebae carrying $P$. aeruginosa from a hospital environment has been described (Michel et al., 1995), and we have shown in this study that $P$. 
aeruginosa PAO1 also causes the formation of extensive vacuolization in Acanthamoeba sp. Vic-1.

Several lines of evidence from our study suggest that intracellular B. cepacia is metabolically active: (i) bacteria in the vacuoles remain motile; (ii) some intracellular bacteria examined by electron microscopy show evidence of septum formation; (iii) the vacuoles of amoebae cocultivated with live $B$. cepacia are characteristically spacious, in contrast with the tight-fitting vacuoles of amoebae cocultivated with either heat-killed B. cepacia or live E. coli. Our results also suggest that intracellular B. cepacia displays a low level of intracellular replication, as indicated by increasing numbers of intracellular bacteria recovered at the latter stages of infection, in contrast to the small number of extracellular bacteria (between 100 and 1000 c.f.u. ml ${ }^{-1}$ ) remaining in the presence of the antibiotic ceftazidime. The overall increase in intracellular bacteria was, however, at best no more than two logarithmic units higher than the amount of intracellular bacteria at the beginning of the experiment. This is in marked contrast to the rapid multiplication of bacteria in amoebaconditioned media. Recently, Steinert et al. (1998) showed conclusively that $M$. avium can grow saprophytically on products secreted by the amoebae, although their experiments did not rule out intracellular multiplication. Since intracellular M. avium was also able to survive within amoebae it is conceivable that these micro-organisms may receive nutrients and grow within the protozoan. The fact that in our study, B. cepacia CEP021 grows much better in amoebae-conditioned medium suggests that these micro-organisms can grow saprophytically, and perhaps the primary mechanism of growth in nature is extracellular in the presence of products secreted by amoebae. Intracellular bacteria may benefit in terms of survival from the protective shield conferred by amoebae, and growth mediated by amoebae by-products. It is not clear how the amoeba kills bacteria but presumably killing is mediated by nonoxidative mechanisms. B. cepacia is known to resist non-oxidative killing by neutrophils (Speert et al., 1994), and this property could also be important for survival within amoebae. Further studies, currently under way in our laboratories, are required to characterize the molecular basis of $B$. cepacia survival within amoebae. Presumably, these properties may also be important in the pathogenesis of B. cepacia infections in CF patients.

\section{ACKNOWLEDGEMENTS}

The authors thank D. Robinson, E. Mahenthiralingam and D. P. Speert, Children's Variety Research Centre, University of British Columbia, M. I. Fernández, Instituto Argentino del Diagnóstico, and J. Smayevsky, CEMIC, University of Buenos Aires, for providing many of the strains used in this study. We also thank H. Aspök, Vienna, for providing us with corneal material from which Acanthamoeba sp. HLA was isolated, G. Gmeiner for technical assistance and K. Kraemer and M. Schusterbauer for processing the prints. This work was supported in part by an Internal Research Grant from the London Health Sciences Centre to M.A.J.

\section{REFERENCES}

Beckman, W. \& Lessie, T. G. (1979). Response of Pseudomonas cepacia to $\beta$-lactam antibiotics: utilization of penicillin $\mathrm{G}$ as the carbon source. J Bacteriol 140, 1126-1128.

Berk, S. G., Ting, R. S., Turner, G. W. \& Ashburn, R. J. (1998). Production of respirable vesicles containing live Legionella pneumophila cells by two Acanthamoeba spp. Appl Environ Microbiol 64, 279-286.

Birtles, R. J., Rowbotham, T. J., Storey, C., Marrie, T. J. \& Raoult, D. (1997). Chlamydia-like obligate parasite of free-living amoebae. Lancet 349, 925-926.

Boulanger, C. A. \& Edelstein, P. H. (1995). Precision and accuracy of recovery of Legionella pneumophila from seeded tap water by filtration and centrifugation. Appl Environ Microbiol 61, 18051809.

Burkholder, W. H. (1950). Sour skin, a bacterial rot of onion bulbs. Phytopathology 40, 115-117.

Burns, J. L., Jonas, M., Chi, E. Y., Clark, D. K., Berger, A. \& Griffith, A. (1996). Invasion of respiratory epithelial cells by Burkholderia (Pseudomonas) cepacia. Infect Immun 64, 4054 4059.

Cirillo, J. D., Falkow, S., Tompkins, L. S. \& Bermudez, L. E. (1997). Interaction of Mycobacterium avium with environmental amoebae enhances virulence. Infect Immun 65, 3759-3767.

De Jonckheere, J. F. (1991). Ecology of Acanthamoeba. Rev Infect Dis 13 (Suppl. 5), S385-S387.

Drabick, J. A., Gracely, E. J., Heidecker, G. J. \& LiPuma, J. J. (1996). Survival of Burkbolderia cepacia on environmental surfaces. J Hosp Infect 32, 267-276.

Elsinghorst, E. A. (1994). Measurement of invasion by gentamicin resistance. Methods Enzymol 236, 405-420.

Essig, A., Heinemann, M., Simnacher, U. \& Marre, R. (1997). Infection of Acanthamoeba castellanii by Chlamydia pneumoniae. Appl Environ Microbiol 63, 1396-1399.

Govan, J. R. W. \& Deretic, V. (1996). Microbial pathogenesis in cystic fibrosis: mucoid Pseudomonas aeruginosa and Burkholderia cepacia. Microbiol Rev 60, 539-574.

Govan, J. R. W. \& Vandamme, P. (1998). Agricultural and medical microbiology: a time for bridging gaps. Microbiology 144, 2373-2375.

Govan, J. R., Hughes, J. E. \& Vandamme, P. (1996). Burkbolderia cepacia: medical, taxonomic and ecological issues. $J$ Med Microbiol 45, 395-407.

Isles, A., Maclusky, I., Corey, M., Gold, R., Prober, C., Fleming, P. \& Levison, H. (1984). Pseudomonas cepacia infection in cystic fibrosis: an emerging problem. J Pediatr 104, 206-210.

Jett, B. D., Hatter, K. L., Huycke, M. M. \& Gilmore, M. S. (1997). Simplified agar plate method for quantifying viable bacteria. Biotechniques 23, 648-650.

Kilvington, S. \& Price, J. (1990). Survival of Legionella pneumophila within cysts of Acanthamoeba polyphaga following chlorine exposure. J Appl Bacteriol 68, 519-525.

Kilvington, S. \& White, D. G. (1994). Acanthamoeba: biology, ecology and human disease. Rev Med Microbiol 5, 12-20.

LiPuma, J. J., Dasen, S. E., Nielson, D. W., Stern, R. C. \& Stull, T. L. (1990). Person-to-person transmission of Pseudomonas cepacia between patients with cystic fibrosis. Lancet 336, 1094-1096.

Ly, T. M. \& Muller, H. E. (1990). Ingested Listeria monocytogenes survive and multiply in protozoa. J Med Microbiol 33, 51-54.

Mergeryan, H. (1991). The prevalence of Acanthamoeba in the human environment. Rev Infect Dis 13 (Suppl. 5), S390-S391. 
Michel, R. \& Hauröder-Philippczyk, B. (1992). Cocultivation of Acanthamoeba castellanii and Pseudomonas aeruginosa leads to infection of the amoebae. Publ Jpn-Ger-Cent Berlin Ser B 5, 174-178.

Michel, R. \& Hauröder-Philippczyk, B. (1994). Acanthamoeba from human mucosa infected with an obligate intracellular parasite. Eur J Protistol 30, 104-110.

Michel, R. \& Hauröder, B. (1997). Isolation of an Acanthamoeba strain with intracellular Burkholderia pickettii infection. Zentbl Bakteriol 285, 541-557.

Michel, R., Burghardt, H. \& Bergmann, H. (1995). Natürliche intrazelluläre Infektion bei Acanthamoeben mit Pseudomonas aeruginosa nach ihrer Isolierung aus einer mikrobiologisch beanstandeten Trinkwasser-Hausinstallation eines Krankenhauses. Zentbl Hyg 196, 532-544.

Page, F. C. (1976). An Illustrated Key to Freshwater and Soil Amoebae. Ambleside, Cumbria: The Ferry House.

Perotto, S. \& Bonfante, P. (1997). Bacterial associations with mycorrhizal fungi: close and distant friends in the rhizosphere. Trends Microbiol 5, 496-501.

Prince, A. (1986). Antibiotic resistance of Pseudomonas species. J Pediatr 108, 830-834.

Rowbotham, T. J. (1980). Preliminary report on the pathogenicity of Legionella pneumophila for freshwater and soil amoebae. J Clin Pathol 33, 1179-1183.

Speert, D. P., Bond, M., Woodman, R. C. \& Curnutte, J. T. (1994). Infection with Pseudomonas cepacia in chronic granulomatosis disease: role of non-oxidative killing by neutrophils in host defense. J Infect Dis 170, 1524-1531.

Steinert, M., Birkness, K., White, E., Fields, B. \& Quinn, F. (1998). Mycobacterium avium bacilli grow saprozoically in coculture with Acanthamoeba polyphaga and survive within cyst walls. Appl Environ Microbiol 64, 2256-2261.

Tablan, O. C., Chroba, T. L., Schidlow, D. V. \& 7 other authors (1985). Pseudomonas cepacia colonization in patients with cystic fibrosis: risk factors and clinical outcome. J Pediatr 107, 382-387.

Vandamme, P., Holmes, B., Vancanneyt, M. \& 8 other authors (1997). Occurrence of multiple genomovars of Burkbolderia cepacia in cystic fibrosis patients and proposal of Burkbolderia multivorans sp. nov. Int J Syst Bacteriol 47, 1188-1200.

Willatt, D. J. (1993). Continuous infrared thermometry of the nasal mucosa. Rbinology 31, 63-67.

Received 14 December 1998; revised 10 March 1999; accepted 19 March 1999. 